\title{
Senator Allison Pays a Debt
}

\author{
By FrederucK F. FAVILLE*
}

The first lieutenant governor of the state of Iowa was Oran Faville who lived on a farm near Mitchell in Mitchell county. He was elected in 1857. In 1860 he had an ambition to go to congress. In the Republican convention that year the contest was close between Oran Faville and a young lawyer from Dubuque named William B. Allison. Allison won the nomination and the election.

In 1870 Allison was a candidate for U. S. senator. At that time United States senators were elected by the General Assembly. The contest before the Thirteenth General Assembly was between Allison and Judge George G. Wright.

Oran Faville's brother, Amos S. Faville, was a member of the house of representatives from the district composed of Mitchell and Howard counties. It was assumed that he would "get even" with Allison for the defeat of his brother for congress. On the contrary he was an enthusiatic and ardent supporter of Allison. However, Allison was defeated in the Thirteenth General Assembly, but was elected in 1872 and began his long and illustrious career as a U. S. senator from Iowa.

Amos S. Faville dropped out of politics entirely. Oran Faville died. Years passed. In 1907 the Iowa delegation of congressmen and senators, all being Republicans, held a caucus in Washington to determine who should be recommended to President Theodore Roosevelt for various federal offices in the northern district of Iowa. Such was the ancient custom.

It was generally conceded that Edward Knott of Waverly, long-time friend and henchman of Senator Allison, would be reappointed as United States Marshal, and

- The author was District U. S. Attorney for the northern Iowa district until 1913. He later served on the Iowa Supreme Court for 13 years, and was editor of the Iowa Code, and Supreme Court reporter before his death in 1954 . 
it was so. The selection of the rest of the appointees was not so easy.

Horace G. McMillan was United States Attorney from the Eleventh Congressional District, and Archie C. Smith from Storm Lake, also in that district, was Collector of Internal Revenue. Congressman Cousins had a candidate for United States Attorney in the person of M. J. Tobin of Vinton. Senator Dolliver and Congressman Birdsall favored Cady Chase of Webster City. Various names were discussed for both positions without arriving at a conclusion. The desire of all was to have complete unanimity in the selections finally made.

The tradition is that Senator Allison characteristically proposed a compromise and suggested that Cousin's candidate for United States Attorney be appointed Collector and that the attorneyship go to someone in the big Eleventh District. Congressman Hubbard from that district agreed to this and he was told to propose a man. He suggested the name of a young lawyer living at Storm Lake who had not been mentioned until then. He said this man's name was Faville. Whereupon Senator Allison said, "That must be a son of the man who voted for me for senator after I had defeated his brother for congressI'd like to pay that debt now." And so Frederick F. Faville, the son of Amos Faville and nephew of Oran Faville, became United States Attorney for the northern district of Iowa, with Mr. Tobin appointed Collector of Internal Revenue.

Thus a "debt" nearly forty years old was paid in good measure by "the Grand Old Man" of Iowa. Who shall dare assert that politicians are ungrateful? Allison wasn't.

Of course a woman doesn't want her plants to freeze, but still one can't blame a man for raising a row when he hops out of bed in the morning and finds a geranium plant in each trouser leg. 
Copyright of Annals of Iowa is the property of State of Iowa, by \& through the State Historical Society of Iowa and its content may not be copied or emailed to multiple sites or posted to a listserv without the copyright holder's express written permission. However, users may print, download, or email articles for individual use. 